\title{
Interaction of Landscape and Settlement Structures in the Danube region
}

\section{AUTHORS:}

\section{L'ubica Vitková ${ }^{*}$}

\section{Olena Lemak ${ }^{2}$}

1, 2 Slovak University of Technology in Bratislava, Faculty of Architecture and Design, Department of Urban Design and Planning, Slovakia

\section{${ }^{*}$ CORRESPONDING AUTHOR \\ E-mail: lubica.vitkova@stuba.sk}

\section{ARTICLE INFO}

Sent: Nov 24, 2020

Accepted: Mar 8, 2021

\begin{abstract}
:
The importance of the identity and quality of urban spaces is currently one of the major professional problems - especially in relation to the rapidly developing urbanization of European settlements. The primary task of urban planners is to support and develop the potential of towns and cities and the quality of their urban structure. At the same time, the formation and transformation of urban structures requires an increasingly consistent approach in terms of sustainable development. A special area of research is the study of the cultural potential and uniqueness of the material and spatial structure of towns and cities and their surroundings. In this respect, it is important to monitor the optimization of the city's macro and micro spaces through an extended analysis of the evaluation of urban and vegetation structures and their historical, cultural and environmental value. By monitoring these factors, we can optimize the processes taking place in the settlement structure, which affect the vitality and identity of urban spaces. A special area is also the monitoring of the projection and penetration of the landscape structure into the urban space. The harmonization of urban and landscape elements can also contribute to the sustainability of tourism. The evaluation of selected towns and cities in the Danube area and their surroundings in terms of the peculiarity of the image of the urban and landscape structure can help to better use the potential of individual settlements and their parts.
\end{abstract}

\section{KEYWORDS:}

town, city, sustainability, Danube, genius loci, identity, image

\section{INTRODUCTION}

When evaluating the quality of urban structure and especially urban spaces, urban planners and landscape architects observe the following aspects: location, type of urban space, its importance, aesthetic character of the place, functional use [1], but also accessibility, spatial orientation, its historical and cultural value. Due to their complexity, urban structures tend to be evaluated based on a variety of criteria, including economic ones. Some authors, such as Alexander Cuthberg [2], or, in our region, Max Wittmann [3] and others, have presented such an evaluation. At present, the emphasis is also on the field of ecology and sustainability of urban structure in relation to the landscape, which is described in the work of Douglas Farr [4]. A special phenomenon is the evaluation of the quality of space, the observation of the Genius Loci - The Spirit of the Place. The Genius Loci is not a new phenomen. It is especially important in the transfer of building types, with respect to preserving the specific character of towns, places or their spirit in this current era of globalization when the model-type solutions are implanted into the urban structure without consideration for the context and peculiarities of the locality. It became more noticable especially after the Second World War, in the period of functionalism. The transmissions of certain models of urbanization and architecture were inherent in the period of colonialism too, but not on such a mass scale.

Several foreign and domestic authors explore the issue of the Genius Loci in their theoretical works. Christian Norberg Shulz [5], Kevin Lynch [6], and Christopher Day [7] are among the pioneers who have consistently developeded this theory. Rem Koolhass also addresses the issue of the city's image in his article Generic City [8]. Alain Theirstein and Agnes Förster [9] examine and evaluate this topic in various contexts, strategies and levels, from region through city/town to town districts. In addition to the evaluation of the character of urban structures or entire regions, the intangible context and memory of the place the spiritual, cultural and historical aspects of Genius loci - are 
also important. This is evident in the publications of Mikuláš Huba and Daniel Kollár, who, together with selected authors, reflect on the peculiarities of Slovakia and its regions to which the authors have a close relationship and with which they identify [10]. In Slovakia, the topic of Genius Loci is explored by Silvia Bašová [11] and L'ubica Vitková [12]. They focus on the image of a town or a city and its districts and especially on public spaces. A. Dobrucká [13] evaluates the importance of Genius Loci in landscape creation.

The individual regions, landscapes and towns and cities have a special character. The character of the territory and place thus defines its uniqueness that distinguishes it from other regions and settlements. In this context, Christian Norberg Schulz's monography "Genius loci" (Norberg-Schulz, 1981) is a pioneering work. In our research, his perception is used as a point of reference. Based on the aspects defined by his work, we have evaluated the selected town. "Space is certainly not a new concept in architectural theory. But space can mean a lot." [5, p. 11]

Why is his research such an inspiration for us? Schulz penetrates deeper in the analysis of a place, into the beginnings of urban structures, from the establishment of settlements and the development of their building elements with an emphasis on geomorphological conditions as well as human actions. No one describes these aspects better than Schulz. If we study space using his perspective, we get a new open approach to analyzing urban spaces, although the subjectivity of the individual will always be present there as well. Each individual image is unique in its own way and has a different content that is only sometimes the same (perhaps not) as the image of another individual. However, these images are close to the general idea, which is more or less convincing $[6$, p. 46]. The purpose of this research is to study the settlement as an object that is largely defined by natural conditions. In the process of its development, it closed or opened to the external wildlife; it grew and acquired an internal structure influenced by natural conditions inherent at the given place.

\section{LANDSCAPE AS A SIGNIFICANT FACTOR IN THE FOR- MATION OF SETTLEMENT STRUCTURE}

For the objective evaluation of historical, cultural, ecological and environmental factors of individual parts of the settlement, it is necessary to acknowledge the richness and the variety of the nature of landscape in which the settlement is set. If we open, for example, a google map and zoom on a settlement, we are likely to find it surrounded by some fields and nature (maybe some natural landmarks - such as mountains, rivers, creeks, or other water bodies or oceans), to which Schulz assigned the term "cosmic series" [5, p. 32]. This means that the first thing we have to accept in the city planning from global perspective is Nature. Nature determines the shape of settlement, its character, dimensions and optimal development; it even determins how the settlement might respond to climatic conditions. As a result, it might also influence our orientation and identification in the urban space.

\section{Orientation and identification}

"Identification and orientation are the basic preconditions for anchoring a person in the world. Identification is the basis for a person's feeling that they belong somewhere. In contrast, orientation allows a person to follow their homo viator (their life journey)." [5, p. 21]

It is possible to find your way in some place but not to identify with it. Then the person just walks through a place without feeling "at home". In contrast, a person may feel "at home", even if a space or a structure is unknown to them. For a person to really belong to a place, however, both assumptions need to be fulfilled, i.e. a person is at home at a given place and, at the same time, identifies with the space $[5$, p. 20].

Orientation is a natural need of man, part of his existential anchor. A structured, clearly legible space in which points of orientation such as a path, boundary, node, area and landmark [6, p. 46] can be defined "... gives the individual a choice and is a starting point for obtaining further information". Therefore, a clear idea of the space in which a person lives and in which they move is important for a person's personal growth. Experience from a suitable physical arrangement of the environment will help us to create a clearer picture of ourselves.

Self-identification - identification with space and its spirit evokes certain feelings and moods in us. They are important for our own success, sense of happiness and balance. The positive interaction between nature, or urban space, and man is essential. However, "it is not possible without nature" - "order, character, light and time - the basic categories of understanding nature" [5, p. 32].

In the context of Schulz's theory, "identifying" means "making friends" with a certain space [5, p. 20]. Identification with space is natural in familiar environment and important for local communities. Lynch also described the perception of a person in their home environment, on a town or city scale.

\section{Landscape structure}

Landscape can have different structures. In terms of human use, it has the following classification:

primary structure - unaffected by humans, existing before humankind (abiotic components, natural resources); secondary structure - land-use elements influenced and shaped by humans (physical forms, human creations); tertiary structure - socioeconomic phenomena constitute a set of intangible elements; (the elements are tied to the primary and secondary structure of the Nature) [5, p. 32-34].

According to Schulz, the primary landscape structure, through the secondary (current) structure, is a source for the tertiary structure - the structure of non-physical, cultural values [5, p. 126].

Schulz described the structure of the landscape from a topographic perspective based on its vastness, and he also divided the landscape according to the Spirit of a natural place into a 
romantic, cosmic, classical and complex landscapes; he used the same classification for architectural structure [5, p. 42 48]. The characteristics of landscape structures correspond to the perception of the types of urban structures by their inhabitants. "When we asked people to describe and somehow characterize their city (Los Angeles) as a whole, they told us that they found it vast, too vast, shapeless and centerless." [6, p. 39].

\section{Settlement in the field}

In terms of perception of a settlement in Nature, Schulz stated that settlements are a closed intimacy, and there is therefore a relationship between figure (settlement) and background ( $\mathrm{Na}$ ture) [2, p. 12] - this is just one of the most powerful of his terms for describing environmental, ecological and cultural values of a settlement - it is also something that was originated by human hand in nature.

Settlements were originally intended to provide a sense of security from the forces of nature. At the same time, however, they became a projection of the image of the nature landscape from which they arose. We can talk about identification with the image of the surrounding nature. The most important thing to realize is that the Genius Loci manifests itself mostly where the settlement is really open to the primary structure of Nature. The prerequisite, however, is a certain degree of friendliness of the landscape towards the settlement.

\section{Dominant and defining natural elements - "cosmic order"}

The dominance of Nature is fundamental for the strength of the identity of a town or a location and their special character, with natural elements in this system being of similar importance. Schulz's "cosmic order" [5, p. 28]. the phenomenon of Nature, which is stable and very difficult to influence, is constant and dominant. It is kind of an existential anchor (big river, mountain range, hill...). A settlement is subject to this cosmic order, thus it adopts it into its structure and adjusts its building elements accordingly.

\section{Genius loci}

Genius Loci - the image of a city or a place combines historical, cultural, ecological and environmental factors, which comprise one psychological image. We can help revive and shape that image.

\section{METHODS OF ANALYSIS OF LANDSCAPE AND URBAN STRUCTURES IN THE DANUBE REGION}

The aim of our paper is to evaluate the Genius Loci of selected settlements in the Danube region using two presented methodologies: Schulz's methodology of landscape assessment and the methodology of urban space assessment used by Lynch.

The first methodology will help us find the starting points (basics of the current structure) and define them correctly; determine the relationship of the municipality to global and local landscape structures, its openness to the surrounding landscape. Lynch's methodology will help us identify the strengths and weaknesses of the urban structure. The conducted analyzes will open the potential of individual locations of the settlement and allow us to determine the basic building elements (natural and urban-architectural ones) and their parameters in relation to the strengthening of the Genius Loci - a harmonious and sustainable urban structure typical of the $21^{\text {st }}$ century.

\section{Evaluation of landscape structure using the methodology of Christian Norberg-Schulz}

As we have already noted - in order to improve the urban structure and its natural elements, it is necessary to analyze in what environmental, geomorphological and landscape conditions the settlements are set. We have analyzed the settlement using individual indicators, which are the starting points of the modulation of the urban structure.

\section{The landscape of a settlement in the Danube Region - Komárno}

Komárno lies at the confluence of the rivers Danube and Váh in the eastern part of the Žitný ostrov (Rye Island). Its development was thus shaped primarily by these two important natural elements, besides other factors. The Danube and the area of Žitný ostrov can be characterized as significant natural phenomena; according to Schulz's methodology, they fall into the category of "Cosmic elements".

The landscape in which the settlement is located is now more influenced by humans than by nature. It consists of fields and small windbreaks, which also serve as biocorridors. It is a cultivated cultural landscape. The order of this landscape - the socalled "cosmic order" is dominated by the Danube. In addition, its strength is amplified by its tributaries, the river Váh, the river Nitra, and other smaller tributaries, river arms, false channels and accompanying floodplain forests, supplemented by wetlands and lakes, as well as the habitat of the Apal Island.

This landscape can be characterized as combined - with a significant and dominant river watercourse, which has affected and formed also the adjacent plain with changing flows and floods. The adjacent and vast plain is, in this duality, more or less, a stabilizing element. However, both elements are influenced by the factor of time, and related transformations, both natural and human-made. The combined character of the landscape also consists in the duality of the primary and the secondary landscape (transformed by humans).

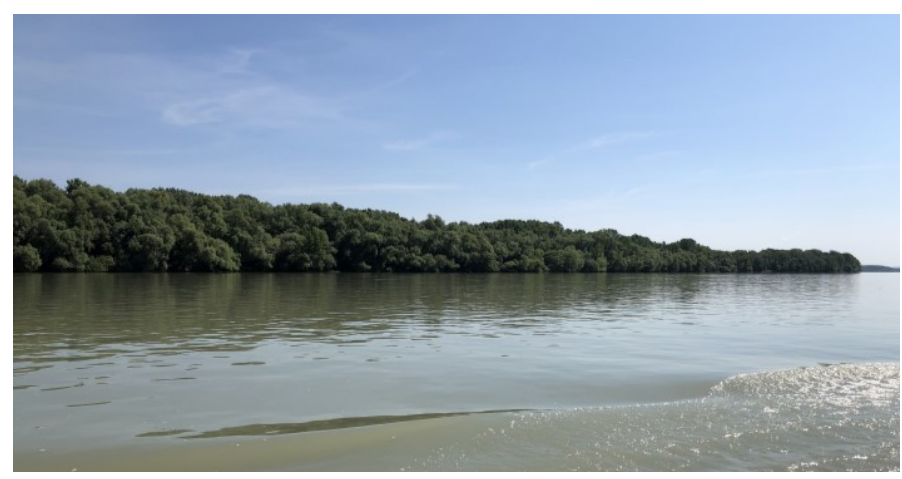

Figure 1: The Danube as a dominant phenomenon in the Danube region. (C L'ubica Vitková 


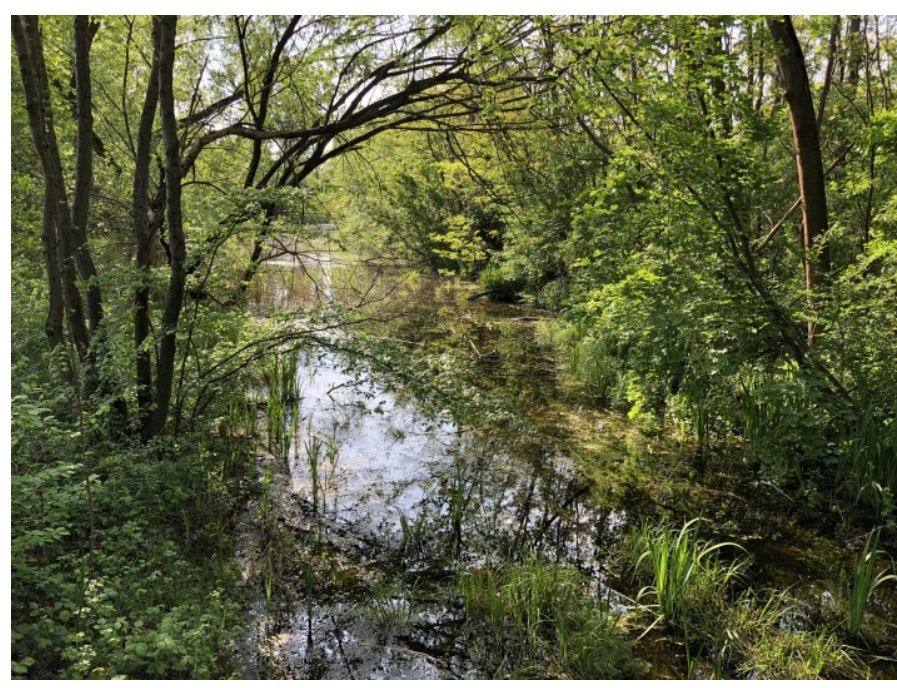

Figure 2: Floodplain forest and branch system of Danube tributaries, as a characteristic part of the Danube landscape. (c) L'ubica Vitková

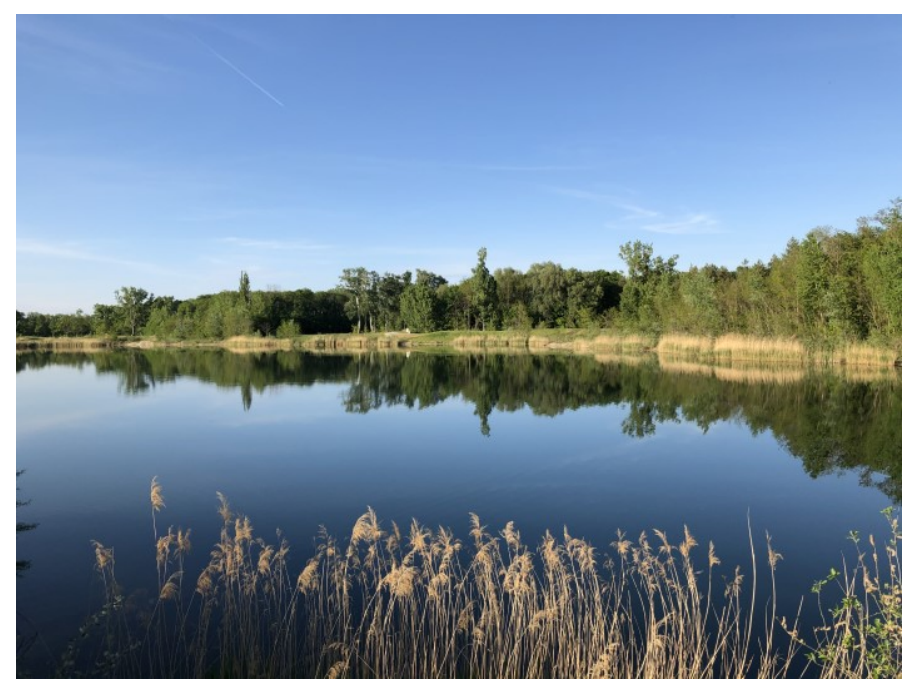

Figure 3: Lake landscape as another phenomenon of the Danube region. (c) L'ubica Vitková

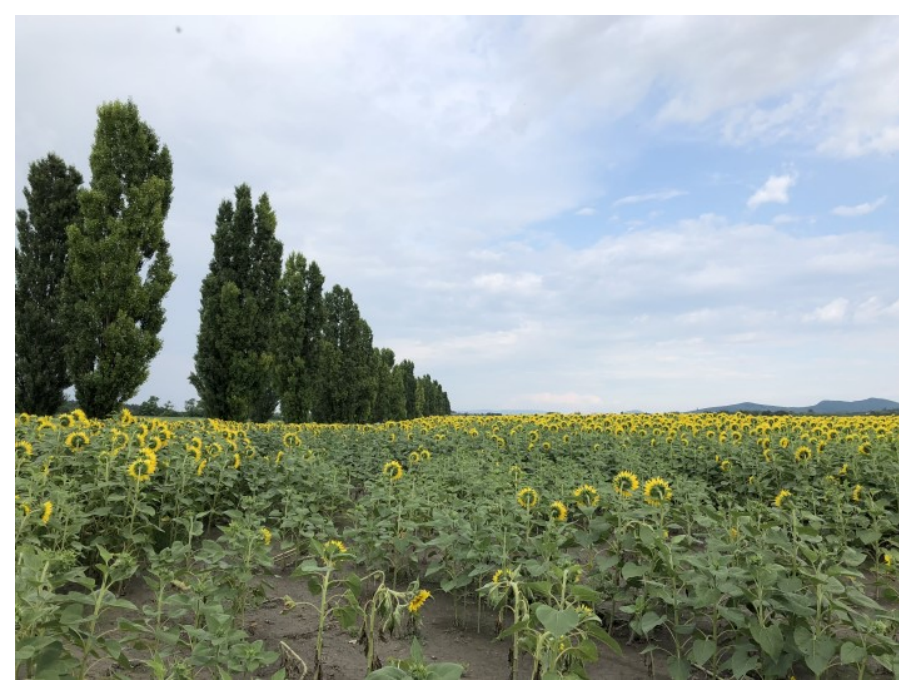

Figure 4: The cultural landscape of the Danube region - cultivated by humans for many centuries. (c) L'ubica Vitková

\section{Geographic and urban framework}

The confluence of the rivers Danube and Váh has also shaped the character of the urban structure of the town. Together with the river Vah, the Danube created the natural boundaries of the town. The strategic location at the confluence of the rivers allowed for the option to build the system of fortifications, which is of a pan-European importance.

The location of the first central European castle at this location was a logical and strategic solution, which was possible because of the landscape. The protection of the object also was strengthened by generations of builders. The natural protection offered by the formations at the confluence of the rivers has been transferred into the structure of the settlement over the centuries. The natural defence of the town was thus strengthened with a system of fortifications behind which the town was hidden. The public spaces inside the town and the town's centre could be "closed off" and protected, which suppored and shaped the spirit of the town - its Genius Loci. The town developed primarily naturally, along the main roads. The urban structure gradually expanded and densified along the street network. In the second half of the $20^{\text {th }}$ century, the town experienced dynamic development related to industrialization - especially the development of shipyards. It constituted a dramatic interference in the original town structure in the form of largescale renovations, but also the expansion of the settlement behind the line of fortifications towards the area of Žitný ostrov. A complex of "new shipyards" and adjacent residential complexes was built in the adjacent open areas behind the fortification system. [15]

The paradox of the town is the persistent duality of openness and closedness to the determining natural factors. The town is open to the existing natural structures in the north (water areas, floodplain forest, Apal Island) or in the east towards the river Váh, especially with its residential structures. However, it still remains closed towards the Danube, where the waterfront areas are occupied by port areas that are inaccessible to the public, as well as in the west, where the city is cut off from agricultural land by an industrial zone and railway lines and partly by a new circuit road.

The town has great development potential due to its location, extraordinary landscape structure and the richness and diversity of the urban structure. However, it does not make sufficient use of this potential, especially in relation to the main natural element - the Danube. Important landmarks of the town are also crucial; they visually connect it with the landscape and, at the same time, have an impact on the image of the town. [15]

The identification of a person with this environment is tied to the quality of the urban structure, public spaces, important landmarks, as well as landscape elements such as rivers, parks and alleys. In this context, the identification of a person with a river is limited to only a few positions (especially in relation to the dominant Danube). The connection of the system of public spaces with the Danube is significantly absent. Another level of identification is the identification of inhabitants with an urban structure, which, with its value, characteristic fortification system, system of dominants and delimitation of public spaces, 
clearly supports the identification of its inhabitants with the town.

It is also interesting to examine the system of public spaces in relation to the landscape. There is an obvious system of routes in the main public spaces towards the landscape in a west-east direction, parallel to the Danube watercouse.
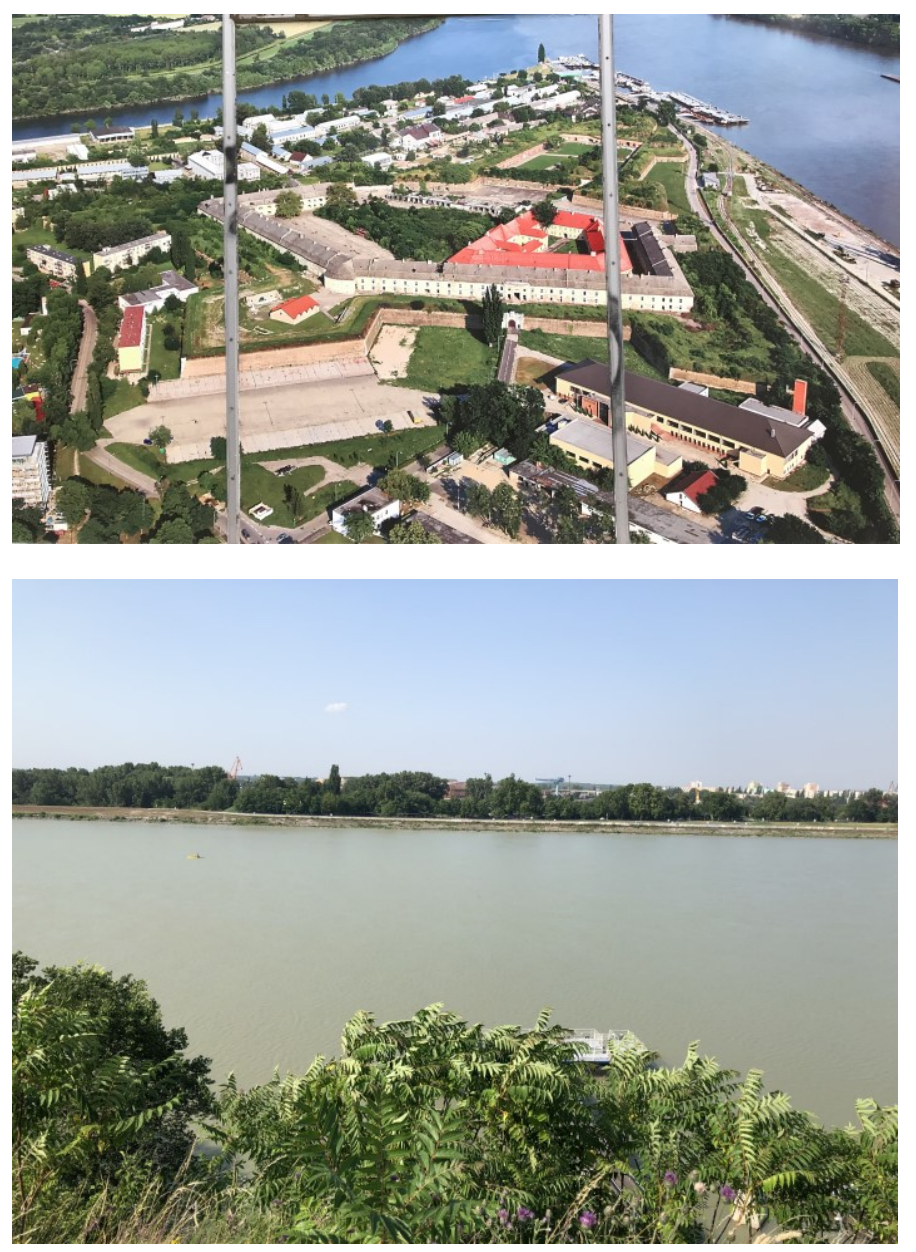

Figure 5, 6: The Danube as a determinant factor of the town of Komarno. (c) L'ubica Vitková

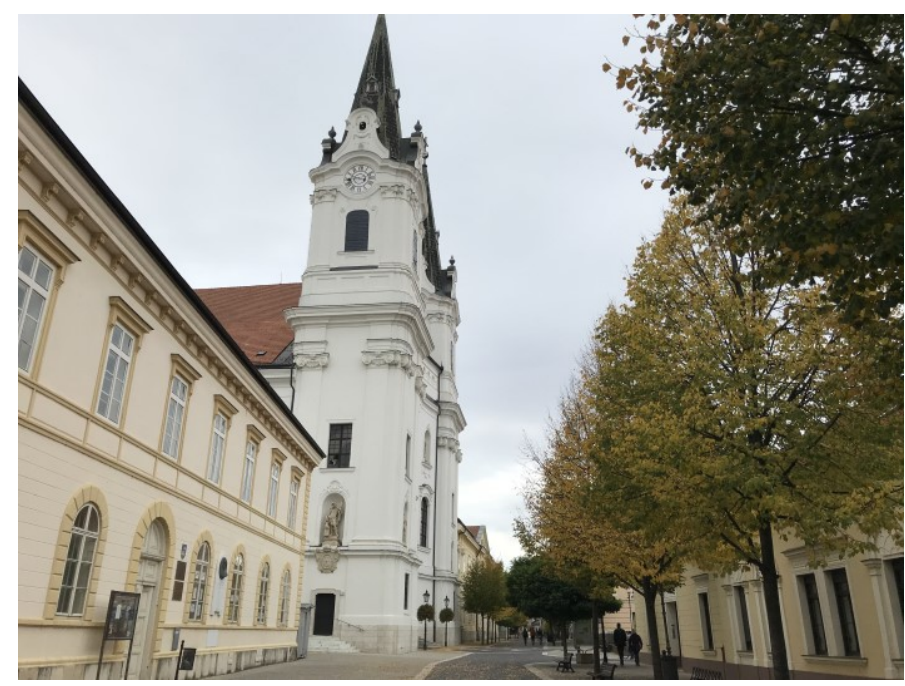

Figure 7: Typical historic urban fabric of Komarno. (c) L'ubica Vitková

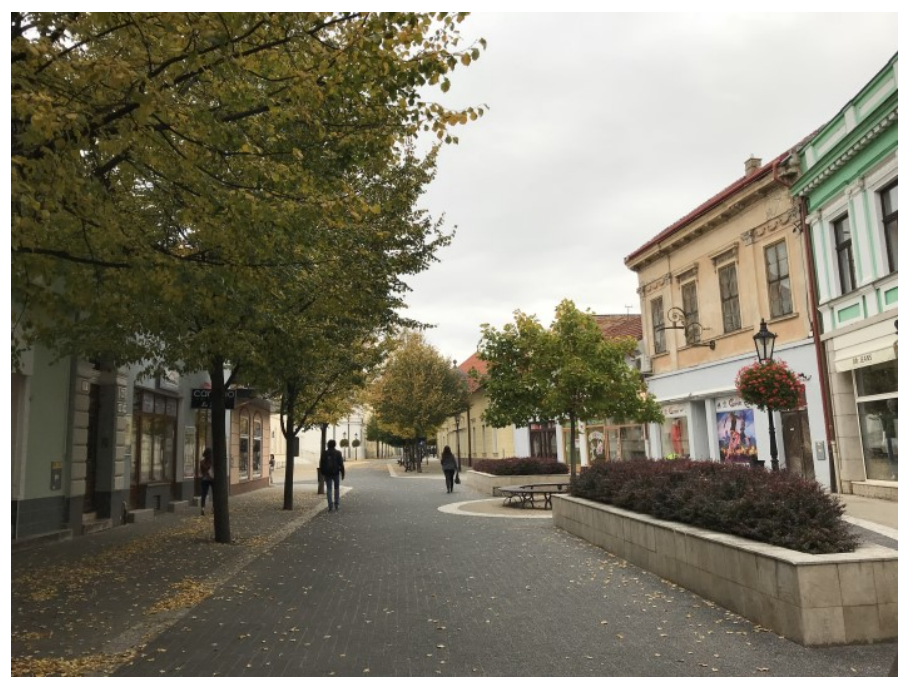

Figure 8: Typical historic urban fabric of Komarno. (c) L'ubica Vitková

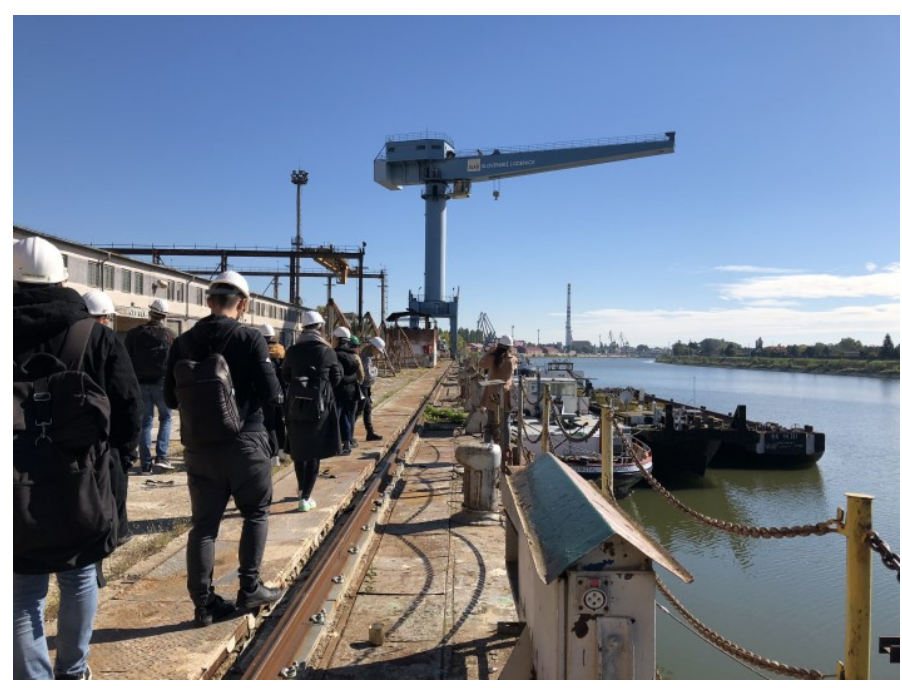

Figure 9: Industrial heritage as an integral part of the town, linked to the Danube. (c) L'ubica Vitková

A special feature of the urban structure of Komárno is its connection with the town of Komárom on the right bank of the river Danube. The above-mentioned confluence represents a phenomenon characteristic for the Danube area, of twin cities developing on the two banks of the river in two states along the entire course of the Danube. In the Slovak-Hungarian part, there are: Komárno - Komárom and Štúrovo-Estergom. The Danube thus plays a dual role. It is both a bonding element and an interface. Komárno and Komárom were originally one of the classic examples of settlements on both sides of the river. The watercourse was an ideal anchor for the establishment of settlements, especially near fords or in strategic defensive locations, which is an example of Komárno. However, throughout history, it has often been subject to geopolitical division where the Danube was the border along which Komarno was divided between two states. Within the urban structure, the original unity of the suburbs is obvious, especially with respect to the preserved system of fortifications on both sides of the river, but also wiith regard to the main operational and compositional axis of both towns connected to the bridge. Schulz described a bridge as an "opening to the world" [5, p. 78]. 


\section{Elizabeth Island}

A special phenomenon of Komárno is Elizabeth Island. It unites the natural landscape (presented by the river and adjacent vegetation) with the urban one. A platan alley was planted on the island. Schulz described a tree as one of the means of connecting the land and the sky, and even as a living organism that greatly affects Genius Loci [5, p. 25]. The platan alley is not only an attractive space for recreational activities and ecotourism, but also a stabilizing element from an ecological perspective.

The greatest value of the island is its natural value, which has great potential for the development of eco-tourism. Elizabeth Island is especially important for the locals, traditionally as an area of gardens, which are now gradually being transformed into the residential environment of houses. The waterfront areas are underused, and the same could be said about the town centre. The human orientation at this location is relatively clear and well-arranged, thanks to the central transverse axis supported by the platan alley or embankment promenades, along the Danube and its arms, although the quality is rather low. [15]

\section{Apal Island}

Another unique natural phenomenon is Apal Island. It is situated at the confluence of the rivers Váh and Nitra. It is a nature reserve of national importance, which preserves the original landscape typical of the area along the rivers of the Danube region. Apal Island is an important element supporting the natural system of the landscape and it is a source of living organisms (fauna). The island is large enough for self-regulation, but needs conservation measures (the carrying capacity of natural reserves is sufficient for self-regulation unless the landscape structure is overburdened by human activity) [16].

\section{Potential of the natural heritage of Komarno and its sur- roundings}

The Danube, the Váh and other rivers - the Little Danube, the Nitra and the Zittau, a system of river arms and false channels, inundation areas, wetlands and floodplain forests form the natural framework of Komárno and its wider flat surrounding area. The characteristic phenomenon of the landscape around Komárno are the river sediments brought by the rivers, especially the Danube, with the extensive floodplain. The characteristic appearance of the current landscape with the cultural agricultural landscape is marked by human activity and shaped by a system of surface streams, old and false river arms with forest vegetation and cultural steppes. [16]

The Danube is a unique phenomenon in itself. The Danube is primarily a connecting element - connecting cultures, nations, and the economy. The Danube thus represents the potential for prosperity and development, the improvement of the quality of life and the richness of activities. [17]
Qualitative and quantitative indicators of primary, secondary and tertiary landscape structure of Komárno

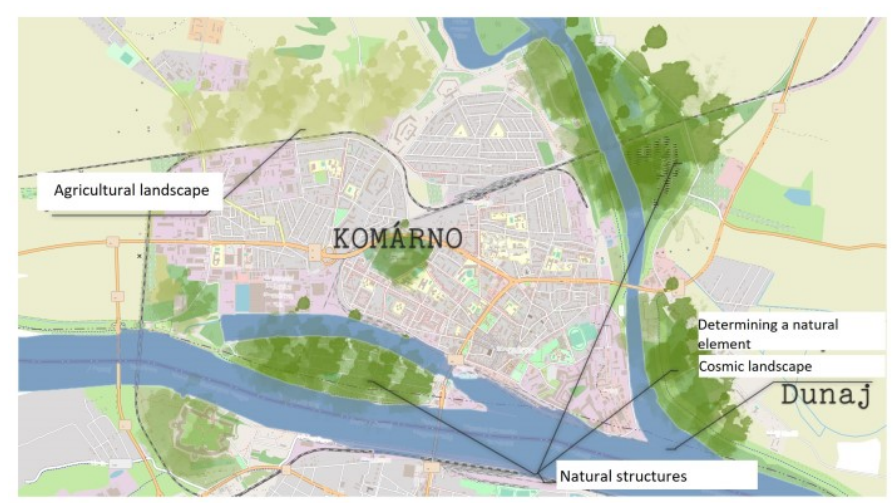

Figure 10: Landscape structure in relation to the town of Komarno. (C) Olena Lemak

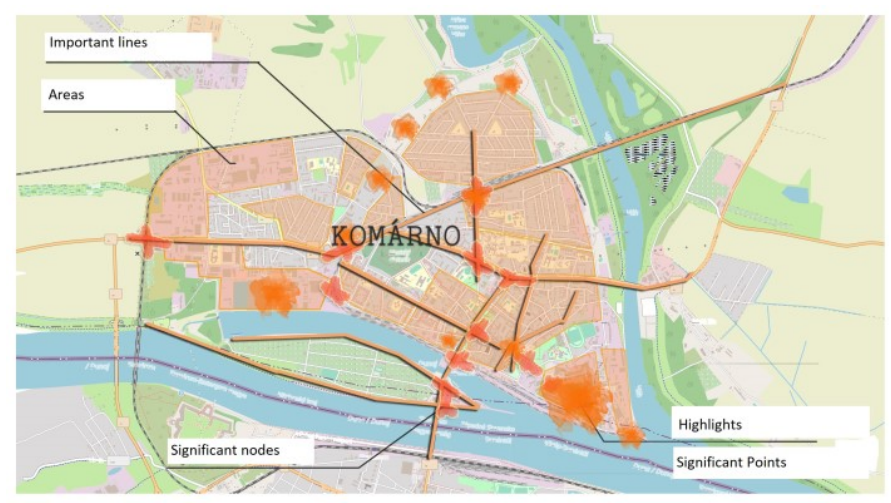

Figure 11 The evaluation of the urban fabric of Komarno. (C) Olena Lemak

The potential of the natural and cultural landscape of the region, in the vicinity of Komárno, as well as the town of Komárno itself with its cultural heritage, including cross-border regions, creates conditions for the development of a wide range of tourist and recreational activities. These can be divided into several thematic areas:

Cultural and cognitive tourism - a network of historical sites, monuments - a system of archaeological sites, fortifications on the Danube, architecture of the socialist period;

\section{Spa and health tourism;}

Rural tourism and agritourism - gastronomy, viticulture, agriculture, traditional crafts;

Summer tourism and recreation close to the water (cycling, water sports, etc.) [17].

The above mentioned areas overlap and enrich each other. 
Table 1: Total evaluation of the landscape structure of the settlement of the Danube Region. Source: L'ubica Vitková, Olena Lemak

\begin{tabular}{ll}
\hline Indicators & Description \\
\hline $\begin{array}{l}\text { Landscape structure } \\
\text { surrounding the town }\end{array}$ & $\begin{array}{l}\text { Northeast - the National Natural Reserve, } \\
\text { along the river Váh, South - the Danube. } \\
\text { Northwest - agricultural land. }\end{array}$ \\
$\begin{array}{l}\text { Geomorphological } \\
\text { structure }\end{array}$ & Flat landscape
\end{tabular}

The vastness
of the town

Climate conditions

Harmonization

of the natural

and urban landscape

The type of landscape structure according to Schulz

Structure of the town overlapping with the natural landscape structure - orientation

Structure of the town overlapping with the natural landscape structure - identification

Internal structure

of the town

- orientation

Internal structure

of the town

- identification

\section{Greenery in the town}

\section{Cultural identity}

The importance and the potential of natural and cultural landscapes

\section{Thematic areas of natural and cultural landscape of the town and its wider surroundings}

It is open towards the rivers (except for the part of the Danube with the fleet) and the National Nature Reserve, closed towards agricultural land

\section{Favourable}

The advantage is that the town is open to the favourable landscape structure, but it has not accepted it enough to reflect Nature inside of the town

\section{Cosmic and combined landscape}

The views of the urban structure from the natural landscape and vice versa.

Identification is possible, thanks to superior natural elements and compactness of the urban structure

It is chaotic in new development areas, and areas after large-scale remediation, in the historic part of the town with a clear hierarchy of spaces and landmarks

It is favourable in the centre of the town and within the borders of homogeneous urban areas

Greenery is concentrated in semi-public and private spaces, without larger systems of green structures in the settlement, and greenery along watercourses;

Sustainability and enhancement of historical structures are needed, and identity of recreation; the town's link to the Danube landscape enhances the identity of this settlement

The town, the wider surroundings of the town, the region, the cross-border regional importance along the Danube

Cultural and cognitive tourism - a network of historical sites, monuments - a system of archaeological sites, fortifications on the Danube, architecture of the socialist period

\section{Spa and health tourism}

Rural tourism and agritourism - gastronomy, viticulture, agriculture, traditional crafts

Summer tourism and recreation close to the water (cycling, water sports, water recreation).

\section{Evaluation of urban structure using Kevin Lynch method- ology}

Lynch explored the peculiarity of the character of a city in his theoretical work. Every city has its own image, a kind of mental image. Lynch defined the term "imageability", i.e. the ability to create or leave an image in memory, thanks to which a person is better oriented in space. The aforementioned image of a city is shaped by its structure, its meaning and peculiarity - identity.

Lynch characterized a city using several characteristics that are associated with its identity. Lynch defined five basic elements to be used to assess the quality of the urban structure: paths, edges, districts, nodes and landmarks that fundamentally shape the image of a city. Areas are defined by edges, interwoven with paths, while important elements as well as nodes have a navigational role in space. These elements can be characterized as follows:

Districts are homogeneous spatial structures within the city with the same, clearly legible character.

Edges define the interface between the individual areas. They are linear elements such as banks, railway corridors, but also the boundaries of buildings, walls, etc.

Nodes are important spatial landmarks in a city. In the system of public spaces, these are mainly their nodal elements squares. They are points and strategic places in a city, such as the intersections of important streets, crossings, entrances, transition areas, or areas where one structure transforms into another. The efficiency of nodal spaces is increased by the placement of significant spatial features - landmarks or important elements.

Landmarks constitute identification and orientation elements of the urban structure. They are usually easily distinguishable objects - landmarks, important buildings, hills, but also elements that help people to fix and associate the city and its image in their memory.

Paths constitute a system of linear spaces in the urban structure, such as streets and arterial roads, but also rivers, water canals, railway routes, which can help us navigate through space.

As part of the evaluation of the urban structure, Lynch also evaluated other characteristics of the urban structure, such as: uniqueness, simplicity of form, simplicity of interconnection, distinction of directions, continuity, dominance, visual range, time series. He explored these properties in their synergies.

Lynch linked the evaluation of urban structure to movement and activity in space; furthermore, he emphasized the importance of examining their intensity and quality. "Creating a city is an art that takes place over time" [6, p. 1], which makes us realize that a city is in a permanent transformation process, which affects the factor of development.

The development aspect is reflected, for example, in the term "development axis", along which the city develops and which 
connects the centre of the city with the natural landscape. Therefore, the main spatial concept in the form of a system of public spaces is essential for the city. The role of an architect, an urban planner as a creator is "to shape the whole city so that one can perceive it in its entirety, but also in its individual parts." $[6$, p. 13].

Table 2: Evaluation of the urban structure of Komarno. Based on Lynch's theory, Komárno can bedivided into several characteristic areas. Source: L'ubica Vitková, Olena Lemak

\begin{tabular}{ll}
\hline Indicators & Description \\
\hline Districts & $\begin{array}{l}\text { Historical centre, residential } \\
\text { structures of the socialist period, } \\
\text { family residences }\end{array}$ \\
Edges & $\begin{array}{l}\text { Waterfront, fortress line, agricultural } \\
\text { landscape }\end{array}$
\end{tabular}

Nodes

Entrances to the town, to the historic centre, important squares of the town

Paths

Supporting system of public spaces, supporting system of roads, railway, the Danube river

Landmarks

Fortress, fortification system, churches, historic and public buildings

Cultural values

The historic centre of the town, historical and technical monuments and buildings

The landscape structure reflection in the inner structure of the town

The Danube canal, green axis along the fortress and fortification system, the Elizabeth Island, floodplain forest has been preserved Openness to the landscape $\begin{aligned} & \text { Closed, partially open in some } \\ & \text { positions }\end{aligned}$

1) Along the main road to the West, and along the Danube

Potential development axes

2) Towards the river Váh, and along the river in the eastern part of the town

\section{CONCLUSION}

The presented research focused on the analysis of the interaction of landscape and urban structures. It presents selected principles of analysis of the landscape and urban structure of a settlement with the focus on the evaluation of the identity of a town, through the assessment of spatial quality. These analyzes help us to specify the peculiarities of the spatial structure of a settlement in relation to its surroundings, to define their strengths and the potential that should be developed.

Orientation and identification are the two basic needs of a person in space. Human orientation depends to a large extent on the quality of the urban structure, the quality of public spaces, their legibility, accessibility, appropriately situated landmarks and other factors. The character of the city's public spaces and the route system is influenced by historical development, but also by the basic natural conditions and the character of the surrounding landscape.
The harmonization of urban structures and their spaces with the surrounding landscape is the basis of the town's sustainability and at the same time the basis of its Genius Loci, co-creating its identity. It has been formed during the historical development of the town, and also by events, technical progress and knowledge. Identity is connected with a special image of a town or a place.

The presented paper is an output of the DANUrB project (Danube Urban Brand a regional network building through tourism and education to strengthen the "Danube" cultural identity and solidarity) and supported by the DANUrB + project (DANube Urban Brand + Building Regional and Local Resilience through the Valorization of Danube's Cultural Heritage).

\section{REFERENCES:}

[1] Babalis, D. (2016) "Cultural Heritage and Innovative Design Value", In: Approaching the integrative city. The Dynamics of Urban Space, Firenze, Altralinea Eduzioni, Italy, Vol. 84, pp. 18.

[2] Cuthbert, A.R. (2011) "Understanding cities. Method in Urban Design", London and New York, Routledge, USA, pp. 330.

[3] Wittmann, M., et al. (2017) "Mezi domy, mezi lidmi? Význam volných prostorů pro udržitelný urbánní rozvoj”, Brno, Akademické nakladatelství CERM, Czech Republic, pp. 351.

[4] Farr, D. (2008) "Sustainable Urbanism", Urban Design

with Nature, New Jersey, Willey, USA, pp. 303.

[5] Norberg-Schulz, Ch. (2010) "Genius loci. Krajina, místo, architektúra", Praha, Dokořan, Czech Republic, $2^{\text {nd }}$ edition, $p p$.

11, 20, 21, 25, 28, 32, 42-48, 78, 126.

[6] Lynch, K. (2004) "Obraz mesta”, Praha, Bova Polygon,

Czech Republic, pp. 1, 13, 39, 46.

[7] Day, Ch. (2004) "Duch a místo", Era, Czech Republic, pp. 273.

[8] Koolhaas, R. (1995) "The Generic City", In: SMLXL, New York, Monacelli Press, USA, pp. 1238-1266.

[9] Theirstein, A., Förster, A. (2008) "The Image and the Region - Making Mega City Regions Visible”, Munich, Lars Muller Publishers, Germany, pp. 288.

[10] Huba, M., Kollár, D. (2011) "Genius loci". (Roz)hovory o Slovensku, Bratislava, Dajama, Slovakia, pp. 119.

[11] Bašová, S. (2004) "Identita a integrita tradičných vidieckych sídiel a ich hodnoty pre súčasný vidiecky život”, In: Monumentorum tutela 15, Monitoring svetového dedičstva, Banská Štiavnica, Bratislava, Slovakia, Pamiatkový úrad, pp.188-191.

[12] Vitková, L'. (2014) “Sila génia loci”, Urbanita, Vol. 26 (3), pp. 10-13.

[13] Dobrucká, A. (2014) "Génius loci a krajinná tvorba", Urbanita, Vol. 26 (3), pp. 28-32.

[14] Supuka, J., Hreško, J. - Končeková, L. (2009) “Krajinná ekológia", Nitra, SPU, Slovakia, pp. 32-34.

[15] Vitková, L'. (2018) "Východiská pre rozvoj a transformáciu mesta Komárno v rámci projektu DANUrB", In: DANUrB - Impulzy pre Komárno. Impulses for Komárno. Bratislava, Spektrum STU, Slovakia, pp. 16-29.

[16] Kristiánová, K. (2018) "Krajinno-architektonické prístupy a zelená infraštruktúra v metodike výskumu a metodike výučby urbanistickej tvorby na príklade Komárna", In: DANUrB - Impulzy pre Komárno. Impulses for Komárno. Bratislava, Spektrum STU, Slovakia, pp. 52-56.

[17] Kádár, B. - Vitková, L'. (2019) "Sustainability options for tourism development", In: Book on the unexplored cultural her- 
itage in communities by the Danube : DANUrB 2017 - 2019,

Praha, Gasset, Czech Republic, pp. 88-95. 